\title{
IDENTIFIKASI POLA AKTIVITAS PADA RUANG TERBUKA PUBLIK DI KAMPUNG GAMPINGAN KOTA YOGYAKARTA
}

\author{
Sidhi Pramudito ${ }^{1 *}$, Bezaliel Tera Kurnialohi ${ }^{2}$ \\ Program Studi Arsitektur Fakultas Teknik Universitas Atma Jaya Yogyakarta1, \\ Program Studi Arsitektur Fakultas Teknik Universitas Atma Jaya Yogyakarta ${ }^{2}$ \\ e-mail: *1sidhi.pramudito@uajy.ac.id, 2bezaliel.tera@gmail.com
}

\begin{abstract}
Abstrak_ Kampung Gampingan merupakan salah satu pemukiman padat di kota Yogyakarta. Namun dalam kondisi tersebut, masih dapat ditemukan keberadaan ruang terbuka publik berupa plaza. Ruang terbuka publik itu adalah lapangan multifungsi yang dimanfaatkan warga untuk beraktivitas baik individu maupun kelompok. Hal ini yang menjadi perhatian bagi penulis untuk dapat mengidentifikasi pola aktivitas warga dalam memanfaatkan ruang tersebut sebagai satu-satunya ruang terbuka publik dengan tipologi plaza di kampung ini. Penelitian ini menggunakan metode deskriptif-kualitatif dengan pendekatan teori behavioral setting. Pengumpulan data dilakukan dengan cara survei lokasi, wawancara, dan mendokumentasikan kegiatan masyarakat kampung pada saat pagi hari, siang hari, sore hari, dan malam hari pada di hari kerja (Senin s.d Jumat) serta hari libur (Sabtu s.d Minggu) dengan pembagian area menjadi 5 macam ruang aktivitas. Temuan data dianalisis dengan metode place centered mapping. Hasil dari penelitian ini ditemukan bahwa pola aktivitas warga pada ruang terbuka publik ini adalah terklaster berdasarkan tujuan yang ditentukan oleh ragam atribut ruang, material, ukuran ruang, dan hubungan ruang dengan sekitarnya. Pada ruang ini teridentifikasi kecenderungan pola aktivitas warga yang terkonsentrasi pada area tertentu yang dipengaruhi oleh ragam atribut ruang.Sisi selatan, timur, barat, dan area tengah menjadi area yang cukup dominan dimanfaatkan warga untuk berbagai aktivitas interaksi warga. Berbeda dengan sisi utara yang minim aktivitas interaksi. Hal yang menjadi faktor penentu adanya aktivitas interaksi adalah keragaman atribut ruang serta dimensi ruang. Sebagai rekomendasi, penambahan jumlah dan kualitas atribut ruang dapat menjadi salah satu usulan yang harapannya dapat meratakan aktivitas di ruang terbuka publik dengan tipologi plaza ini.
\end{abstract}

Kata kunci: Pola Aktivitas; Ruang Terbuka Publik; Kampung Gampingan; Yogyakarta.

\begin{abstract}
Kampung Gampingan is one of the densest settlements in the city of Yogyakarta. However, the existence of public open spaces such as plazas can still be found. The public open space is a multifunctional field that is used by residents to do activities for both individuals and groups. This is of concern to the writer to be able to identify the pattern of community activities in utilizing the space as the only public open space with plaza typology in this village. This study uses a descriptive-qualitative method with a behavioral setting theory approach. Data collection is done by location survey, interview, and documenting community activities in the morning, afternoon, evening, and evening on weekdays (Monday-Friday) and holidays (Saturday-Sunday) with the division of the area into 5 types of activity space. Data findings were analyzed by the place centered mapping method. The results of this study found that the pattern of citizen activity in this public open space is clustered based on objectives determined by the variety of attributes of space, material, size of space, and the relationship of space with its surroundings. In this space, a trend of residents' activity patterns that are concentrated in certain areas is identified which is influenced by various spatial attributes. The south, east, west, and central areas are areas that are quite dominant for residents to use for various citizen interaction activities. In contrast to the north side which has minimal interaction activity. The thing that determines the existence of interaction activities is the diversity of spatial attributes and spatial dimensions. As a recommendation, increasing the number and quality of space attributes can be one of the proposals which hopefully can even out activities in public open spaces with this plaza typology.
\end{abstract}

Keyword:Pattern of Activities; Public Open Space; Kampung Gampingan; Yogyakarta.

\footnotetext{
${ }^{1}$ Program Studi Arsitektur Fakultas Teknik Universitas Atma Jaya Yogyakarta

2 Program Studi Arsitektur Fakultas Teknik Universitas Atma Jaya Yogyakarta
} 


\section{PENDAHULUAN}

Beragamnya pembahasan mengenai ruang terbuka publik menandakan bahwa sampai saat ini ruang terbuka publik masih menjadi suatu hal yang menarik untuk dipelajari. Ruang terbuka publik merupakan ruang milik bersama, tempat masyarakat melakukan aktivitas fungsional dan ritualnya dalam suatu ikatan komunitas, baik kehidupan sehari-hari maupun dalam perayaan berkala yang telah ditetapkan sebagai sesuatu yang terbuka, tempat masyarakat melakukan aktivitas pribadi dan kelompok (Carr 1992) dalam (Romantiaulia and Ikhsan 2018).Ruang terbuka publik oleh masyarakat dapat dimanfaatkan sebagai tempat untuk bersantai, bermain, berjalan jalan, dan membaca (Nazaruddin 1994). Beberapa definisi tersebut mungkin dapat berlaku pada kondisi yang ideal, namun bagaimana jika ruang terbuka publik tersebut terletak di permukiman yang padat? Aktivitas dan tatanan fisik ruang terbuka publik tersebut tentu memiliki karakteristik tersendiri. Hal tersebut menjadi menarik untuk dibahas lebih dalam, tentang ragam aktivitas apa yang terjadi serta tatanan fisik seperti apa yang ada pada ruang terbuka publik tersebut.

Penelitian tentang ruang terbuka publik sebenarnya sudah banyak dilakukan, dimana hampir sebagian besar membahas tentang aktivitas dan tatanan fisik yang terdapat pada ruang tersebut. Pembahasan mengenai 2 (dua) hal tersebut sebagian besar dilakukan pada kasus ruang terbuka publik yang memiliki dimensi yang luas, terletak di lokasi strategis sebagai ruang rekreasi, sengaja dirancang, dan didukung oleh fasilitas tambahan di sekitarnya. Dalam penelitian ini, penulis mencoba untuk melihat hal yang sama, namun dengan kondisi yang berbeda, yakni kondisi ruang terbuka publik terletak di permukiman padat dan 'tidak' dilengkapi dengan fasilitas-fasilitas pendukung yang memadai. Hasil penelitian ini diharapkan dapat menjadi pertimbangan Pemerintah Kota Yogyakarta apabila di kemudian hari akan melakukan penataan kawasan permukiman padat, khususnya ruang terbuka publik agar dapat sesuai dan berhasil dalam mengakomodasi pengguna dan aktivitasnya.

Menurut (Carmona, Heath and Steve Tiesdell 2010) dalam (Marhendra, Wulandari and Pamungkas 2014) ada beberapa faktor yang dapat dilihat dari hubungan pengguna aktivitas dengan ruang terbuka publik itu sendiri, yakni: (1) Comfort: Rasa nyaman dipengaruhi oleh faktor lingkungan (terhindar dari matahari, angin, dan lain-lain), kenyamanan fisik (tempat duduk yang nyaman, dan lain-lain), dan kenyamanan sosial dan psikologis; (2) Relaxation: berarti lebih mengarah tenangnya badan serta pikiran(Carr 1992). Pada ruang publik, natural elements seperti pohon, rumput, elemen air dan pembatas jalan yang membatasi bagian dalam ruang publik membuat pengunjung lebih mudah untuk relaxed. Elemen-elemen estetika yang juga dapat menutup akses secara visual, memberikan masalah keamanan, dan membuat pengunjung tidak ingin memanfaatkan ruang tersebut; (3) Passive engagement: Penggunaan pasif yang dilakukan oleh pengguna ruang publik adalah mengamati lingkungan; (4) Active engagement: Terjadi dalam bentuk aktivitas yang secara langsung melibatkan pengguna (adanya interaksi warga); (5) Discovery: Pengalaman ruang yang beragam akan meningkatkan ketertarikan orang untuk terlibat di suatu ruang publik.

Tujuan penelitian ini adalah untuk mengidentifikasi pola aktivitas warga dalam memanfaatkan ruang tersebut sebagai satu-satunya ruang terbuka publik dengan tipologi plaza di kampung ini. Dalam penelitian ini, aktivitas warga ditinjau dengan menggunakan kajian a rsitektur lingkungan dan perilaku yaitu konsep behavior setting oleh Roger Barker. Behavior setting dapat diartikan secara sederhana sebagai suatu interaksi antara suatu kegiatan dengan tempat yang spesifik. Behavior setting mengandung unsur-unsur sekelompok orang yang melakukan sesuatu kegiatan, aktivitas atau perilaku dari sekelompok orang tersebut, tempat dimana kegiatan tersebut dilakukan, serta waktu spesifik saat kegiatan tersebut dilaksanakan. Konsep behavior setting dikembangkan untuk mengkaji hubungan antara perilaku dan sistem setting ruang. Apa yang menjadi penekanan dalam kajian behavior setting adalah bagaimana kita dapat mengidentifikasi 
perilaku-perilaku yang secara konstan atau berkala muncul pada satu situasi tempat atau setting tertentu (Haryadi and Setiawan 2010).

Dalam penelitian ini, penulis mengambil kasus ruang terbuka publik yang terdapat di Kampung Gampingan yang merupakan salah satu bentuk permukiman kampung padat di kota Yogyakarta. Kampung ini terletak di Kelurahan Pakuncen dimana keluarahan ini termasuk dalam salah satu kawasan kumuh yang menjadi prioritas penataan di kota Yogyakarta (sesuai dengan Keputusan Walikota Yogyakarta Nomor 216 Tahun 2016: Penetapan Lokasi Kawasan Kumuh di Kota Yogyakarta). Di perkotaan, permukiman kampung biasanya cenderung berkembang mengarah pada terbentuknya kawasan kumuh, karena biasanya didominasi oleh masyarakat berpenghasilan rendah (Budihardjo 2006) dalam (Ghifari and Firdausan 2019). Kampung merupakan kawasan permukiman kumuh dengan ketersediaan sarana umum buruk atau tidak ada sama sekali, kerap kawasan ini disebut "slum" atau "squatter" (Turner 1972). Akibat tradisi atau kebiasaan mempertahankan budaya 'kampung' di dalam kehidupan sehari-harinya, maka tatanan fisik kawasan kampung kota dimaksud cenderung tidak tertata dengan baik, tidak teratur dan mengarah ke kondisi kumuh / kusam serta cenderung tidak teratur (Pawitro 2012).

Namun selain hal negatif tersebut, permukiman kampung sebenarnya memiliki keunikan, karena merepresentasikan kekhasan sejarah, kemampuan, usaha, perjuangan, dan bahkan jiwa merdeka warganya; kekhasan pada aspek fisik terletak pada pola-pola fisik yang beragam, organik, sering kali surprising. Keunikan-keunikan ini lah yang sebenarnya jika dikaji secara mendalam dapat berperan sebagai potensi perancangan di masa depan. Pada penelitian ini, Kampung Gampingan yang notabene ditetapkan sebagai kawasan kumuh sebenarnya juga memiliki potensi, yakni masih dapat ditemukan keberadaan ruang terbuka publik yang berbentuk plaza. Ruang tersebut berupa lapangan multifungsi yang dimanfaatkan warga untuk beraktivitas baik individu maupun kelompok. Keberadaan lapangan ini menjadi sebuah elemen vital dalam kampung sebagai ruang interaksi sosial antar masyarakat secara alami. Melalui penelitian ini, penulis berupaya untuk menggali potensi-potensi lokal masyarakat setempat khususnya dalam memanfaatkan ruang terbuka publik tersebut. Hasil dari penelitian ini diharapkan dapat diketahui perilaku dan kebiasaan warga dalam memanfaatkan ruang terbuka publik tersebut, serta mengetahui kekurangan dan kelebihan ruang tersebut yang nantinya dapat digunakan pemerintah setempat sebagai dasar penataan kawasan kumuh di masa yang akan datang.

\section{METODE}

Lingkup kajian pada penelitian ini berfokus pada identifikasi pola aktivitas warga dalam memanfaatkan ruang terbuka publik di Kampung Gampingan Kota Yogyakarta. Penelitian ini termasuk dalam penelitian kualitatif-deskriptif. Untuk mengetahui pola aktivitas warga dalam memanfaatkan ruang terbuka publik di Kampung Gampingan, analisis dilakukan dengan tinjauan teori behavior setting oleh Roger Barker sebagai salah satu konsep penting dalam kajian arsitektur perilaku lingkungan dan perilaku (Haryadi and Setiawan 2010). Pengambilan data dilakukan dengan menggunakan pemetaan perilaku (behavioral mapping). Behavioral mapping digambarkan dalam bentuk sketsa atau diagram mengenai suatu area dimana manusia melakukan berbagai kegiatannya. Tujuannya adalah untuk menggambarkan perilaku dalam peta, mengidentifikasikan jenis dan frekuensi perilaku, serta menunjukkan kaitan antara perilaku tersebut dengan wujud perancangan yang spesifik (Haryadi and Setiawan 2010).

Untuk mencapai tujuan penelitian ini, pemetaan perilaku atau behavioral mapping yang digunakan adalah pemetaan berdasarkan tempat (place-centered mapping). Teknik pemetaan ini digunakan untuk mengetahui bagaimana manusia atau sekelompok manusia memanfaatkan, menggunakan atau mengakomodasikan perilakunya dalam suatu situasi waktu dan tempat 
tertentu. Dengan teknik pemetaan ini, diharapkan dapat diketahui pola-pola aktivitas warga dalam memanfaatkan ruang terbuka publik di Kampung Gampingan. Teknik place centered mapping dilaksanakan melalui beberapa tahap, yaitu:

- Membuat sketsa dari tempat atau setting yang meliputi seluruh unsur fisik yang diperkirakan mempengaruhi perilaku pengguna ruang (berfungsi sebagai peta dasar)

- Membuat daftar macam perilaku yang akan diamati serta menentukan simbol atau tanda sketsa atas setiap perilaku

- Dalam satu kurun waktu tertentu, berbagai perilaku yang terjadi pada tempat tersebut dicatat menggunakan simbol-simbol di peta dasar yang telah disiapkan di tahap awal (Hartati and Ernawati 2018), (Haryadi and Setiawan 2010)

Pengumpulan data dilakukan dengan cara survei lokasi, wawancara, dan mendokumentasikan kegiatan masyarakat kampung pada saat pagi hari, siang hari, sore hari, dan malam hari pada di hari kerja (Senin-Jumat) serta hari libur (Sabtu-Minggu). Fokus pengamatan penelitian ditentukan berdasarkan konsep behavior setting oleh Roger Barker yang mendefinisikan behavior setting sebagai kombinasi stabil antara aktivitas beserta tempatnya dalam waktu tertentu menurut (Laurens 2004), sehingga didapatkan variabel penelitian pada Tabel 1 dan Tabel 2.

Tabel 1. Variabel Penelitian

\begin{tabular}{|c|c|c|c|}
\hline \multicolumn{4}{|c|}{ Definisi Behavior Setting } \\
\hline (Fajarwati 2016) & (Laurens 2004) & $\begin{array}{c}\text { (Haryadi and Setiawan } \\
\text { 2010) }\end{array}$ & $\begin{array}{l}\text { (Barker 1968) dalam (Popov } \\
\text { and Chompalov 2012) }\end{array}$ \\
\hline $\begin{array}{l}\text { Behavior setting sangat } \\
\text { berkaitan erat dengan } \\
\text { lingkungan fisik, begitu pula } \\
\text { sebaliknya }\end{array}$ & $\begin{array}{l}\text { Behavior setting juga dapat } \\
\text { dijelaskan sebagai } \\
\text { kombinasi perilaku dan } \\
\text { lingkungan tertentu }\end{array}$ & $\begin{array}{l}\text { Behavior setting juga dapat } \\
\text { dijelaskan sebagai interaksi } \\
\text { antara suatu kegiatan } \\
\text { dengan tempat yang spesifik } \\
\text { yang meliputi sekelompok } \\
\text { orang sebagai pelaku } \\
\text { aktivitas, perilaku atau } \\
\text { aktivitas, tempat terjadinya } \\
\text { aktivitas, serta waktu } \\
\text { spesifik saat aktivitas } \\
\text { tersebut berlangsung }\end{array}$ & $\begin{array}{l}\text { Poin utama dalam kajian } \\
\text { behavior setting adalah } \\
\text { sekelompok orang, aktivitas, } \\
\text { tempat dan waktu yang } \\
\text { spesifik }\end{array}$ \\
\hline
\end{tabular}

Variabel Penelitian berdasarkan konsep behavior setting: (1) pelaku; (2) aktivitas; (3) tempat terjadinya aktivitas; dan (4) waktu terjadinya aktivitas

Tabel 2. Deskripsi Variabel Penelitian

\begin{tabular}{cll}
\hline No & Variabel & Sub-Variabel \\
\hline 1 & Pelaku & Jenis pelaku \\
\hline & & Usia pelaku \\
\hline 2 & Aktivitas & Jenis aktivitas \\
\hline & & Intensitas aktivitas \\
\hline 3 & Tempat terjadinya aktivitas & Jenis ruang \\
\hline & & Hubungan ruang \\
\hline & & Atribut ruang \\
\hline 4 & Waktu terjadinya aktivitas & Hari kerja (pagi, siang, sore, malam) \\
\hline & & Hari libur (pagi, siang, sore, malam) \\
\hline
\end{tabular}

Pemetaan pola aktivitas masyarakat dilakukan pada lokasi lingkungan sekitarnya, dimulai pada hari kerja Senin hingga Jumat dan hari libur Sabtu hingga Minggu. Pengamatan di lapangan dibagi menjadi empat sesi yaitu sesi pagi (pukul 08.00 sampai 11.00 WIB), sesi siang (pukul 13.00 sampai $15.00 \mathrm{WIB}$ ), sesi sore (pukul 16.00 sampai $18.00 \mathrm{WIB}$ ), sesi malam (19.00 sampai 22.00 WIB). Pembagian waktu dilakukan berdasarkan frekuensi pengguna dalam menggunakan ruang terbuka publik yang ada. Data yang terkumpul kemudian dikelompokkan berdasarkan variabel penelitian untuk memperoleh temuan tentang kecenderungan warga dalam menggunakan lapangan sebagai ruang terbuka publik di Kampung Gampingan. Selain itu, dapat disimpulkan juga 
kekurangan maupun potensi yang dapat dikembangkan pada ruang tersebut untuk rancangan di masa yang akan datang.

\section{A. Profil Kampung Gampingan}

Kampung Gampingan berada di Kelurahan Pakuncen, Kecamatan Wirobrajan, Kota Yogyakarta dan terbagi menjadi tiga RW, yakni RW 09, RW 10, dan RW 11. Secara keseluruhan, posisi Kampung Gampingan terhadap Propinsi DIY dapat dilihat pada Gambar 1.

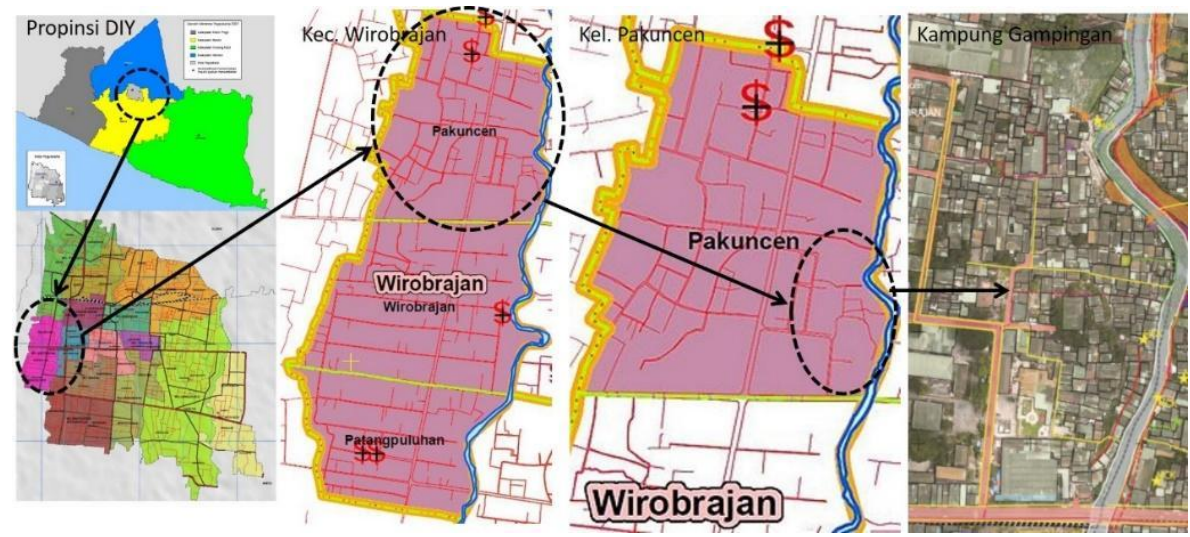

Gambar 1. Posisi Kampung Gampingan terhadap Propinsi DIY

Sumber: https://id.wikipedia.org/; https://peta-hd.com/peta-kota-yogyakarta/diakses Juli 2020, diolah oleh penulis

Batas-batas administratifKampung Gampingan adalah: (1) Utara: RW 08, Kelurahan Pakuncen; Timur: Sungai Winongo dan Kecamatan Ngampilan; Selatan: Jl. RE Martadinata dan Kelurahan Wirobrajan; Barat: Jl. HOS Cokroaminoto dan RW 06-07, Pakuncen. Kampung Gampingan juga didominasi oleh permukiman penduduk yang beberapa diantaranya tumbuh secara organik. Kondisi tersebut semakin terlihat pada permukiman yang terdapat di bantaran Sungai Winongo (Pramudito, Praptantya and Nasir 2019). Beberapa warga banyak yang membangun rumah dengan menggunakan area tersebut. Kondisi bantaran Sungai Winongo berupa sungai bertebing di sisi kanan dan kirinya dan bertanggul. Deskripsi batas administrasi Kampung Gampingan dapat dilihat pada Gambar 2.
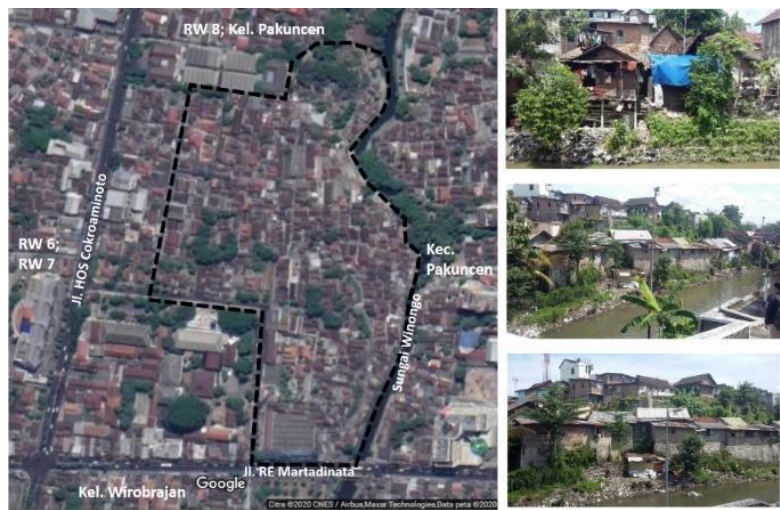

Gambar 2. Batas Administratif Kampung Gampingan (kiri); Kondisi Fisik Permukiman Kampung Gampingan (kanan) Sumber: Peta Google yang Diolah Penulis, 2020

\section{B. Pemilihan Lokus Penelitian}

Lokus penelitian berada di RW 11 Kampung Gampingan. RW 11 merupakan salah satu RW di Kelurahan Pakuncen yang ditetapkan sebagai kawasan kumuh Kota Yogyakarta berdasarkan SK Walikota No 216/2016. RW 11 terdiri dari 4 RT yakni RT 48, 49, 50, dan 51.Lokasi penelitian terletak di lapangan bulu tangkis RT.51 RW.11, Kampung Gampingan, 
Pakuncen, Yogyakarta dengan luas $120 \mathrm{~m}^{2}$, dengan batas-batas: : (1) Utara: rumah warga; Barat: jalan/gang kampung, rumah-rumah warga; Selatan: jalan/gang kampung, rumah-rumah warga; Timur: jalan/gang kampung, Café Secret Garden Coffee \& Chocolate. Pemilihan kasus studi berupa lapangan bulu tangkis didasari pada fungsi lapangan tersebut sebagai ruang terbuka publik. Setelah dilakukan peninjauan lapangan, dapat diketahui bahwa lapangan bulu tangkis tersebut merupakan satu-satunya ruang terbuka publik yang ada pada kawasan tersebut. Lapangan ini selalu ramai digunakan warga setiap harinya sebab dapat menampung segala aktivitas warga dengan kapasitas yang cukup banyak. Secara detail, gambaran mengenai lokasi penelitian dapat dilihat pada Gambar 3.

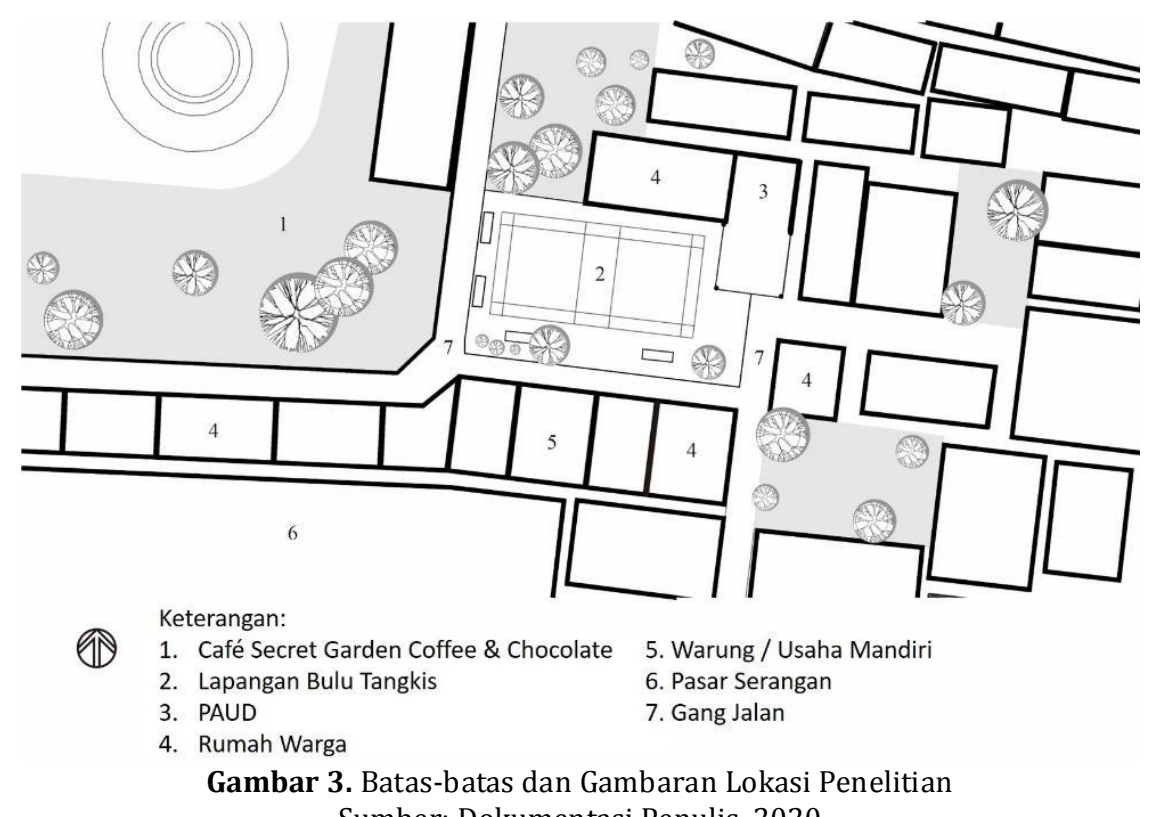

Sumber: Dokumentasi Penulis, 2020

\section{HASIL DAN PEMBAHASAN}

\section{A. Hasil Pengamatan Pola Aktivitas Warga Berdasarkan Waktu}

Dalam penelitian ini, pengamatan dilakukan selama empat kali pada waktu hari kerja dan waktu hari libur,dengan rentang waktu pengamatan yaitu pagi (08.00-11.00 WIB), siang (13.00-15.00 WIB), sore (16.00-18.00 WIB), dan malam (19.00-22.00 WIB). Pola aktivitas di lapangan bulutangkis RW 11 RT 51 dipengaruhi oleh bentuk dan hubungan ruang yang ada di lapangan dan elemen pembentuk ruang di dalamnya. Pola aktivitas masyarakat secara umum dibagi menjadi 5 (lima) yaitu: (1) menjemur; (2) duduk-duduk; (3) parkir; (4) berjalan; dan (5) bermain. Dokumentasi aktivitas masyarakat secara umum dapat dilihat pada Gambar 4.
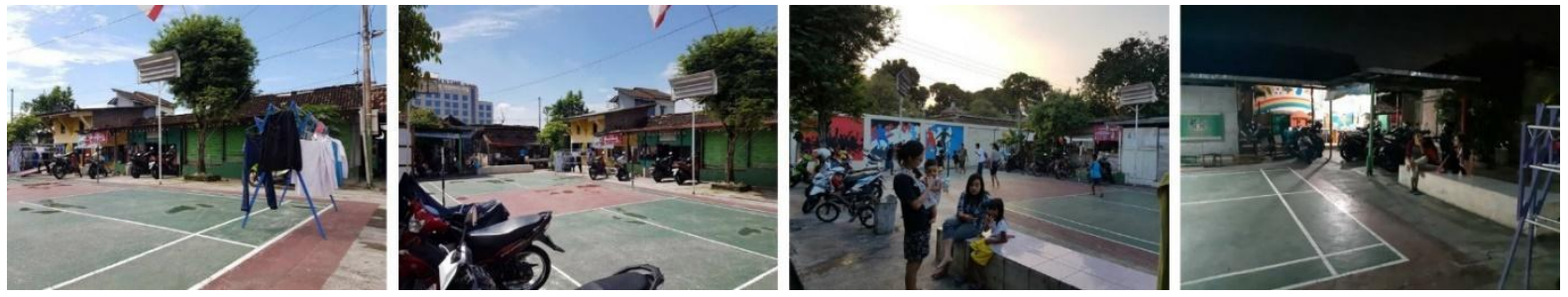

Gambar 4. Aktivitas Masyarakat secara Umum di Lapangan Bulu Tangkis (Pagi-Malam) Sumber: Dokumentasi Penulis, 2019 
Pengelompokan aktivitas didasari oleh kegiatan masyarakat secara umum yang sering dilakukan pada saat menggunakan lapangan bulutangkis ini. Agar analisis data pola aktivitas di lapangan bulutangkis dilakukan secara efektif, penulis membagi area lapangan bulutangkis menjadi empat bagian yaitu: (1) Barat: area lapangan bulutangkis dekat dengan jalan gang yang berbatasan dinding Café Secret Garden Coffee \& Chocolate; (2) Timur: area lapangan bulutangkis dekat dengan area PAUD; (3) Selatan: area lapangan bulutangkis dekat dengan rumah warga dan jalan gang; (4) Utara: area lapangan bulutangkis sisi utara berbatasan dengan rumah warga; dan (5) Tengah: area lapangan bulutangkis. Pembagian 4 (empat) area amatan dapat dilihat pada Gambar 4.

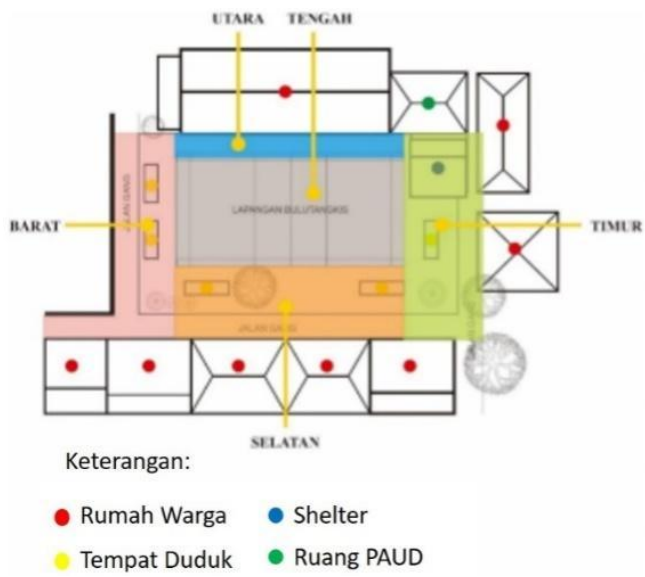

Gambar 5. Peta Kasus Studi Penelitian dan Pembagian Zona Analisis Sumber: Analisis Penulis, 2019

Secara lebih detail, pola aktivitas warga dalam memanfaatkan lapangan bulu tangkis dapat dibagi menjadi pola aktivitas pada hari kerja dan pola aktivitas pada hari libur. Kedua pola aktivitas tersebut dapat diamati pada Tabel 3 dan Tabel 4.

Tabel 3. Pemetaan Pola Aktivitas pada Hari Kerja (Senin-Jumat)

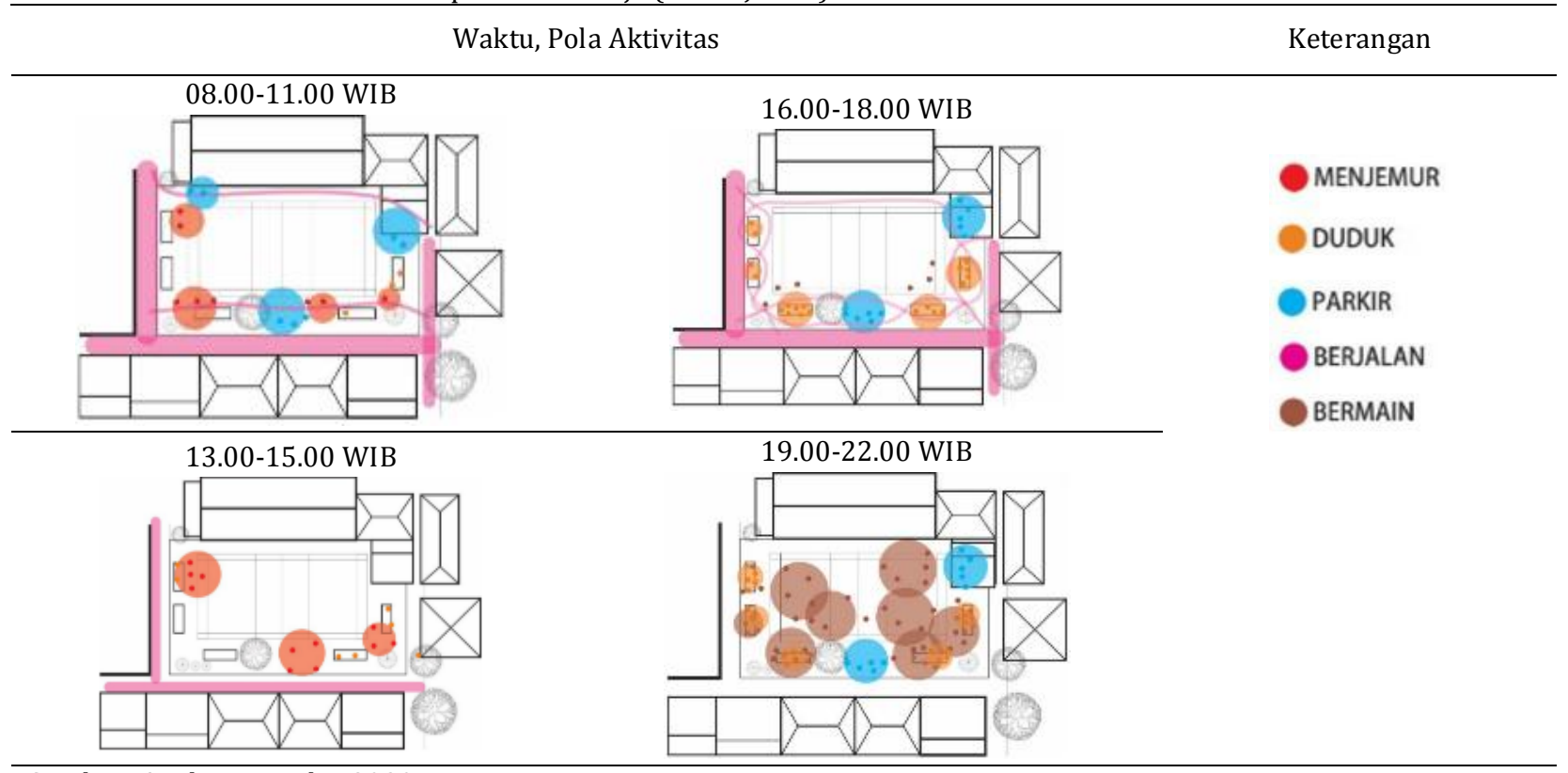

Sumber: Analisis Penulis, 2020 
Tabel 4. Pemetaan Pola Aktivitas pada Hari Libur (Sabtu-Minggu)

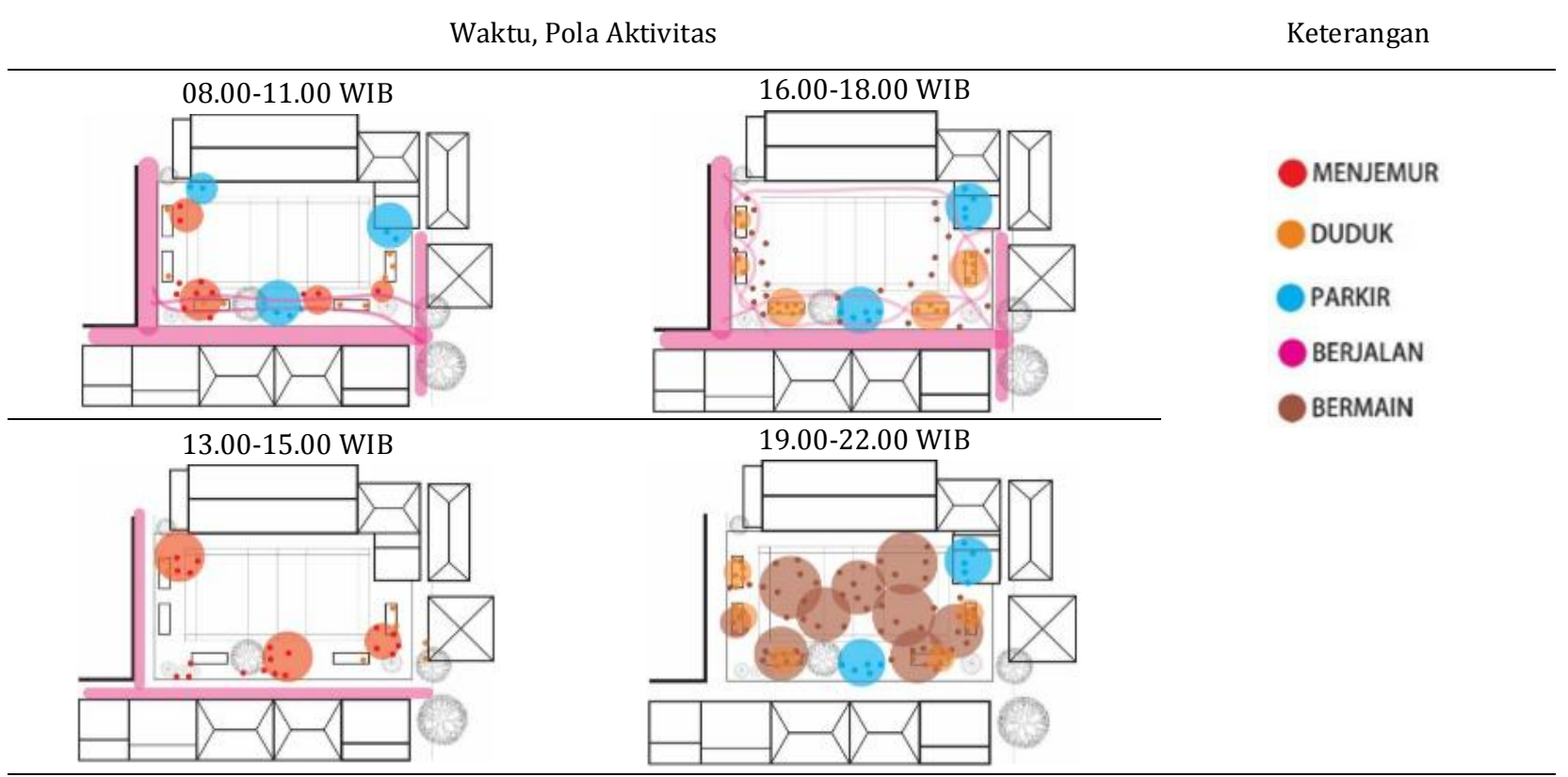

Sumber: Analisis Penulis, 2019

\section{B. Analisis Hasil Pengamatan Pola Aktivitas Warga Berdasarkan Variabel dari Teori Behavior Setting}

\section{Sisi Utara}

Hasil pengamatan aktivitas menunjukkan tidak ada aktivitas yang dominan di sisi utara lapangan ini baik pada hari kerja (Senin-Jumat) maupun hari libur (Sabtu-Minggu). Area sisi utara ini sebenarnya berbatasan dengan rumah warga namun terhalang oleh beberapa bangunan semi permanen, sehingga warga tidak dapat leluasa untuk mengakses area ini. Area ini jarang digunakan warga untuk beraktivitas kecuali di siang hari (13.00 15.00 WIB) sebagai area untuk menjemur pakaian. Aktivitas berjalan sesekali saja terjadi karena letak area ini yang cenderung terisolir karena adanya beberapa bangunansemi permanen. Atribut ruang di sisi utara yaitu lampu penerangan lapangan. Tidak ada tempat duduk dan shelter pada area ini.

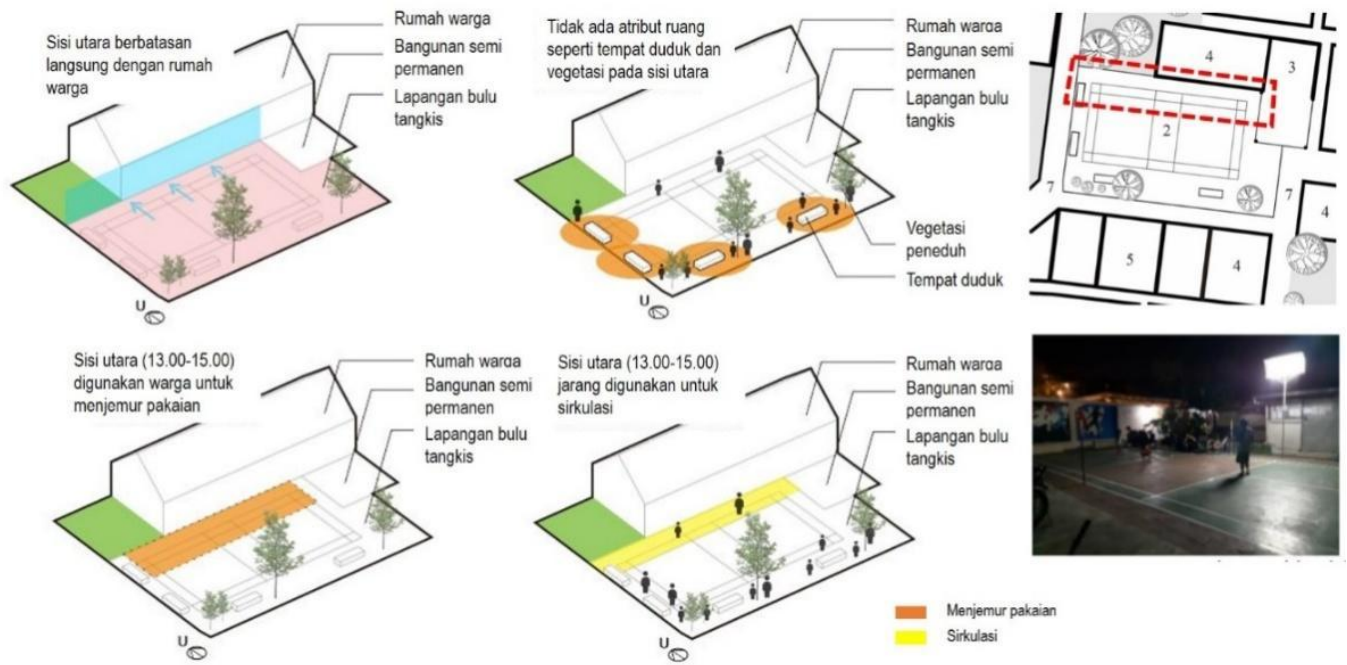

Gambar 5. Analisis Pola Aktivitas Warga di Sisi Utara Lapangan Bulu Tangkis Sumber: Dokumentasi Penulis, 2019 


\section{Sisi Selatan}

Hasil pengamatan aktivitas warga di sisi selatan lapangan bulutangkis pada pagi hari (08.00-11.00 WIB) di hari kerja menunjukkan aktivitas berjalan, duduk, dan memarkirkan kendaraan. Aktivitas berjalan banyak dilakukan karena masyarakat menggunakan jalan di sisi selatan sebagai jalan penghubung area timur dan barat kampung. Material yang digunakan pada jalan ini adalah perkerasan paving block. Atribut ruang pada area ini berupa tempat duduk dan lampu penerangan. Pelaku aktivitas di pagi hari didominasi oleh pelajar, orang tua, dan pedagang yang berjalan kaki di jalan (gang). Anak-anak usia bawah lima tahun (balita) juga terlihat melakukan aktivitas bermain disepanjang jalan dan duduk di tempat duduk lapangan bulutangkis.

Terdapat 2 (dua) tempat duduk sebagai atribut ruang di sisi selatan yang menghadap ke utara (menghadap lapangan bulutangkis) dan menghadap ke selatan (menghadap rumah warga). Aktivitas masyarakat yang duduk menggunakan tempat duduk ini didominasi pada sore hari (16.00-18.00 WIB) dan malam hari (19.00-22.00 WIB). Pada waktu malam, kondisi sisi selatan terlihat ramai dan terdapat berbagai macam aktivitas seperti anak-anak yang bermain, duduk, mengobrol, dan berjalan. Intensitas aktivitas duduk di area tempat duduk akan meningkat ketika lapangan bulutangkis digunakan untuk olahraga bulutangkis pada malam hari di hari libur.
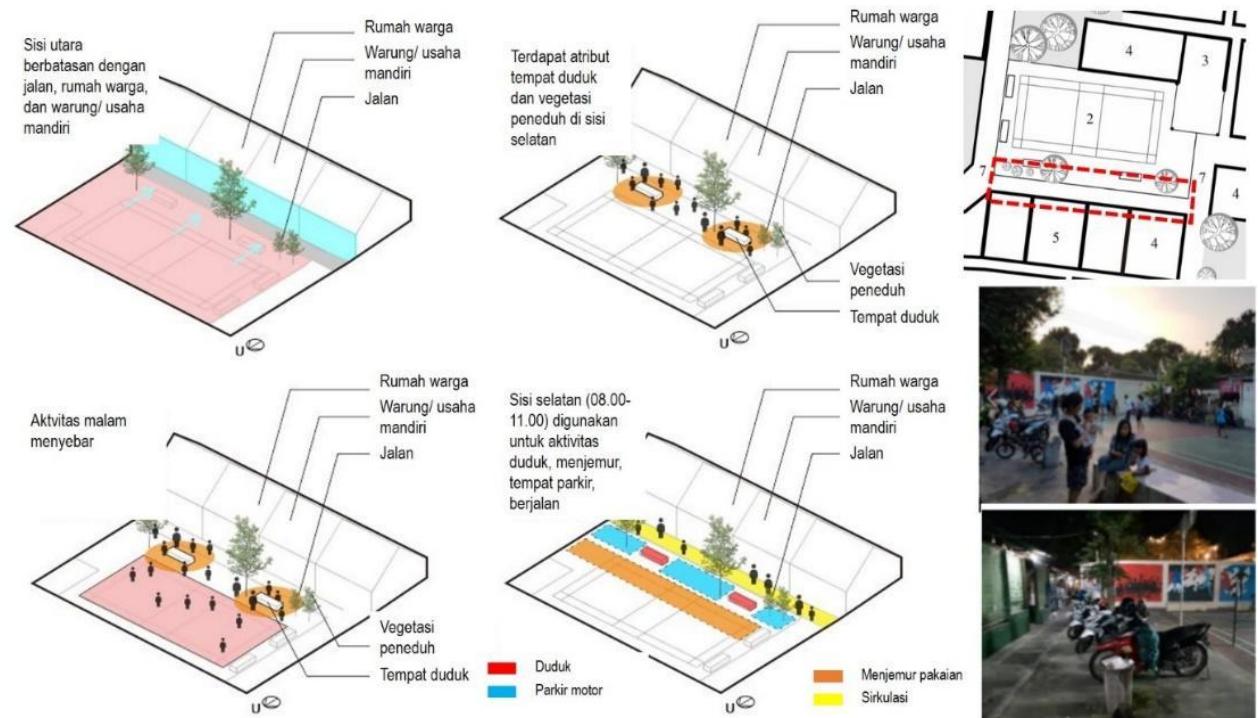

Gambar 6. Analisis Pola Aktivitas Warga di Sisi Selatan Lapangan Bulu Tangkis

Sumber: Dokumentasi Penulis, 2019

\section{Sisi Timur}

Hasil pengamatan aktivitas warga di sisi timur lapangan bulutangkis dan pada pagi hari (08.00 WIB-11.00 WIB) di hari kerja menunjukkan aktivitas berjalan, duduk, dan memarkir kendaraan. Aktivitas berjalan banyak dilakukan karena masyarakat menggunakan jalan di sisi timur untuk mengakses area PAUD di sebelah utara dan mengakses pasar di sebelah selatan, serta mengambil kendaraan yang parkir di shelter dekat PAUD. Material yang digunakan pada jalan ini adalah perkerasan paving block. Adanya material tersebut mempermudah pejalan kaki untuk mengakses setiap area yang ada di sekitarnya. Atribut ruang pada sisi timur ini berupa shelter dan tempat duduk yang digunakan masyarakat untuk beraktivitas. Aktivitas yang dominan pada pagi hari yaitu duduk, berjalan, menjemur pakaian, dan memarkir sepeda motor pada shelter yang tidak bersekat namun memiliki atap sebagai naungan.

Ketika siang hari (13.00-15.00 WIB), aktivitas menjemur pakaian mendominasi area ini. Intensitas aktivitas berjalan kaki mengalami penurunan. Atribut ruang berupa shelter 
digunakan untuk aktivitas ibu-ibu yang duduk dan bersosialisasi. Fungsi shelter akan berubah menjadi area untuk aktivitas memasak ketika lapangan bulutangkis digunakan untuk acara-acara komunal dengan skala besar seperti malam tirakatan, peringatan HUT RI, dan pertemuan kampung. Aktivitas anak-anak berupa kegiatan bermain tidak terlihat pada siang hari. Tempat duduk sebagai sarana penunjang aktivitas tidak digunakan pada siang hari karena material tempat duduk terbuat dari keramik yang membuat tempat duduk panas dan tidak nyaman untuk digunakan. Aktivitas bapak-bapak yang duduk dan bersosialisasi berada di pinggir rumah warga yang menghadap ke barat (menghadap ke lapangan bulutangkis). Area ini menjadi ruang yang aktif karena memiliki tritisan sebagai perlindungan cuaca panas ketika siang hari.

Pengamatan pola aktivitas pada sore hari (16.00-18.00 WIB) di sisi timur menunjukkan aktivitas yang beragam. Aktivitas yang terjadi yaitu duduk, berjalan, dan memarkir kendaraan bermotor. Aktivitas duduk dan bersosialisasi anak-anak usia 5-13 tahun, ibu-ibu mendominasi area ini. Aktivitas tersebut terjadi di sekitar atribut ruang tempat duduk.

Ketika malam hari (19.00-22.00 WIB), aktivitas yang tampak yaitu aktivitas bapakbapak yang duduk dan bersosialisasi. Aktivitas anak-anak bermain tetap terlihat di area ini. Shelter yang semula digunakan untuk ruang sosialisasi berubah menjadi ruang untuk aktivitas memarkir kendaraan. Pada hari libur, aktivitas di sisi timur didominasi oleh bapak-bapak yang menyiapkan alat olahraga bulu tangkis. Area depan rumah warga yang menghadap ke barat (menghadap ke lapangan) digunakan untuk aktivitas duduk, minum, dan bersosialisasi.
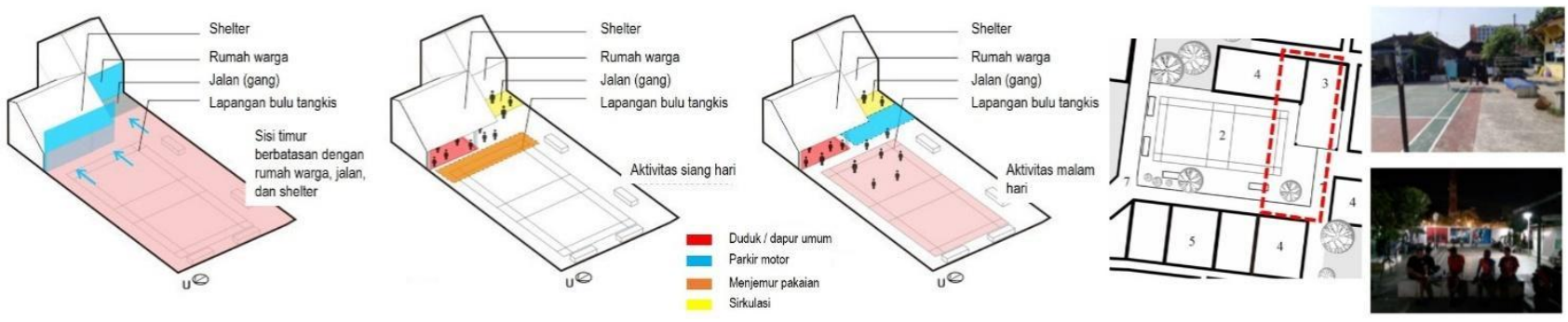

Gambar 7. Analisis Pola Aktivitas Warga di Sisi Timur Lapangan Bulu Tangkis Sumber: Dokumentasi Penulis, 2019

\section{Sisi Barat}

Hasil pengamatan aktivitas warga di sisi barat lapangan bulutangkis pada pada pagi hari (08.00 WIB-11.00 WIB) di hari kerja menunjukkan aktivitas berjalan, duduk, memarkir kendaraan. Aktivitas berjalan(kendaraan maupun pejalan kaki) merupakan aktivitas yang dominan terjadi di area ini. Pada waktu pagi, pelaku aktivitas berjalan didominasi oleh oleh anak-anak yang menggunakan area ini untuk sirkulasi ke luar kampung (menuju sekolahnya).Aktivitas berjalan ini didukung material perkerasan paving block yang membantu pejalan kaki maupun pengendara kendaraan untuk melakukan berbagai aktivitas. Area ini juga digunakan anak-anak untuk bermain dengan durasi yang singkat karena dimensi ruang yang terbatas.

Aktivitas yang dominan dilakukan berikutnya adalah duduk. Area sisi barat ini dilengkapi dengan atribut ruang berupa 2 (dua) tempat duduk yang menghadap ke timur dan barat untuk memenuhi kebutuhan aktivitas di area ini. Masyarakat yang menggunakan tempat duduk di sisi barat dominan duduk menghadap ke timur (menghadap langsung ke lapangan bulutangkis). Secara keseluruhan, pola aktivitas di sisi barat pada pagi hari didominasi oleh pengguna pejalan kaki di jalan gang untuk sirkulasi dan duduk di tempat duduk lapangan. 
Pada siang hari (13.00-15.00 WIB), aktivitas duduk dan berjalan berkurang. Atribut ruang di sisi barat yaitu tempat duduk tidak digunakan dan frekuensi pejalan kaki berkurang. Aktivitas yang dominan di area ini yaitu menjemur pakaian. Sebagian besar masyarakat yang tinggal di kampung Gampingan tidak memiliki cukup lahan untuk menjemur pakaiannya. Sore hari (16.00-18.00 WIB), aktivitas di sisi barat didominasi aktivitas pejalan kaki dan pengguna kendaraan bermotor di jalan gang. Aktivitas duduk yang dilakukan oleh anak-anak dan terjadi pada atribut ruang tempat duduk. Anak-anak usia 5-13 tahun mendominasi area ini untuk bermain dan bersosialisasi.

Malam hari (19.00-22.00 WIB), area sisi barat lapangan bulutangkis didominasi oleh aktivitas duduk di area tempat duduk yang menghadap timur maupun barat. Aktivitas ini didominasi oleh remaja usia 13-17 tahun yang duduk dan bermain gadget karena koneksi wifi gratis dariCafé Secret Garden Coffee \& Chocolate yang terletak di sebelah barat area ini. Pengamatan pada hari libur (Sabtu-Minggu), aktivitas di sisi barat tidak jauh berbeda dengan hari biasa. Frekuensi aktivitas anak-anak yang duduk di atribut tempat duduk bertambah dikarenakan hari libur sekolah.

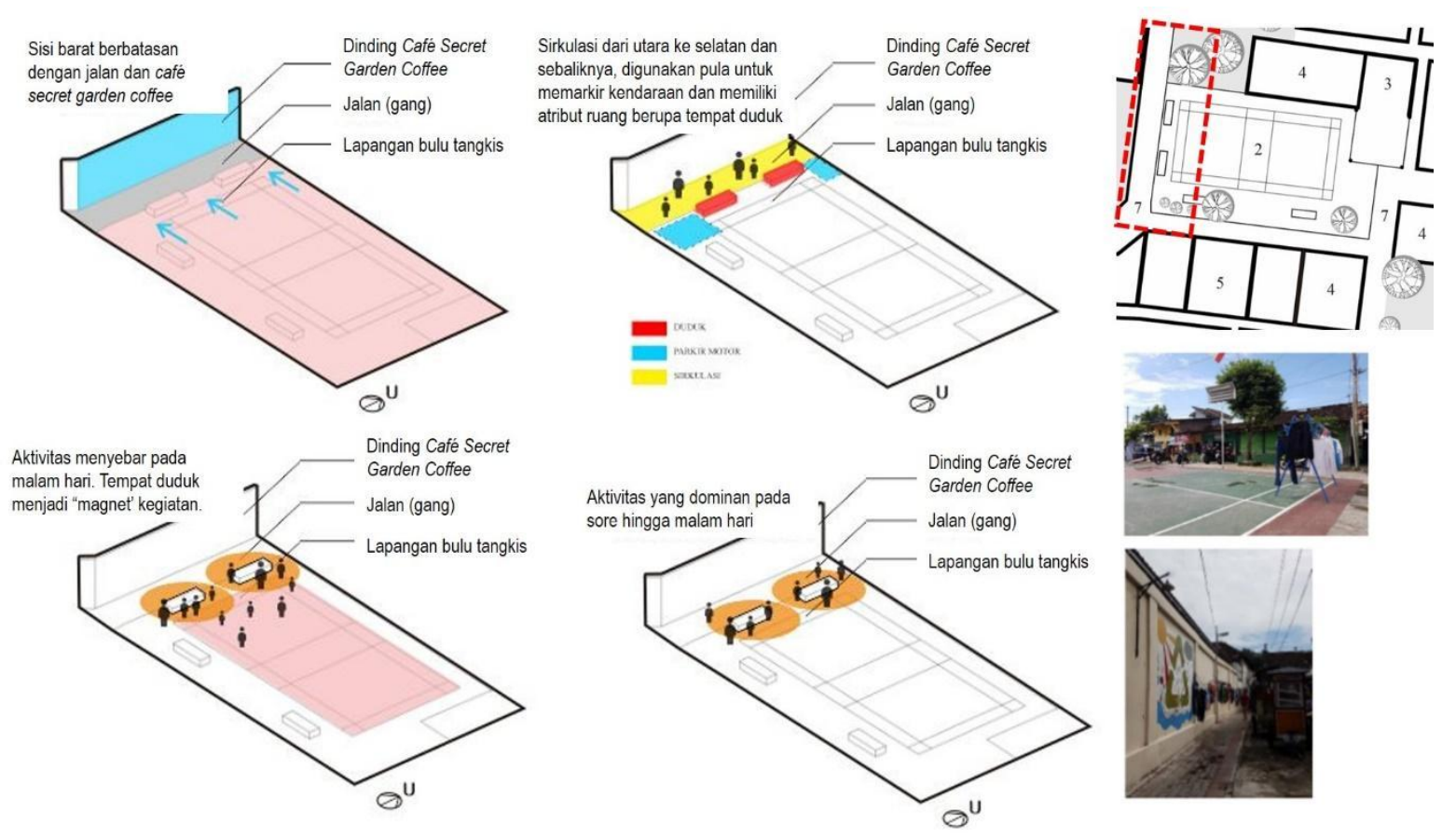

Gambar 8. Analisis Pola Aktivitas Warga di Sisi Barat Lapangan Bulu Tangkis Sumber: Dokumentasi Penulis, 2019

\section{Area Tengah Lapangan Bulu Tangkis}

Hasil pengamatan aktivitas warga di area tengah lapangan bulutangkis pada pada pagi hari (08.00 WIB-11.00 WIB) di hari kerja menunjukkan aktivitas berjalan dan menjemur pakaian. Aktivitas menjemur pakaian dominan terjadi area ini karena area tengah lapangan cukup luas dan terbuka. Lapangan bulutangkis memiliki perkerasan semen sehingga ruang ini termasuk dalam ruang aktif yang dapat menampung berbagai aktivitas masyarakat dalam waktu yang hampir bersamaan. Pada waktu sore hingga malam hari, lapangan bulutangkis menjadi pusat aktivitas masyarakat sekitar, khususnya anak-anak usia 5-13 tahun yang menggunakan lapangan ini untuk bermain dan berolahraga. Atribut ruang di lapangan bulutangkis yaitu 2 (dua) lampu penerangan sebagai pencahayaan aktivitas olahraga. 
Hasil pengamatan aktivitas warga di lapangan bulutangkis pada hari libur menunjukan aktivitas olahraga. Selain itu, area tengah ini juga sering digunakan untuk aktivitas berkumpul seluruh warga kampung seperti ketika terdapat acara khusus seperti malam tirakatan, peringatan HUT RI, serta pertemuan kampung.
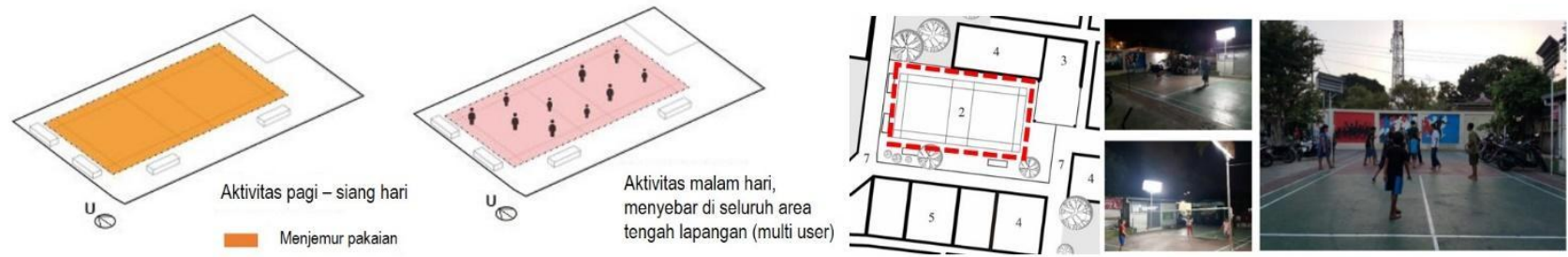

Gambar 9. Analisis Pola Aktivitas Warga di Area Tengah Lapangan Bulu Tangkis Sumber: Dokumentasi Penulis, 2019

\section{Analisis Komparasi Pola Aktivitas Warga}

Dari hasil analisis aktivitas di masing-masing area, pada tahap ini penulis mencoba melihat kecenderungan pola aktivitas warga yang terjadi secara keseluruhan di lapangan bulu tangkis. Secara keseluruhan, pola aktivitas warga dalam memanfaatkan lapangan bulu tangkis sebagai ruang terbuka publik kampung adalah sebagai berikut:

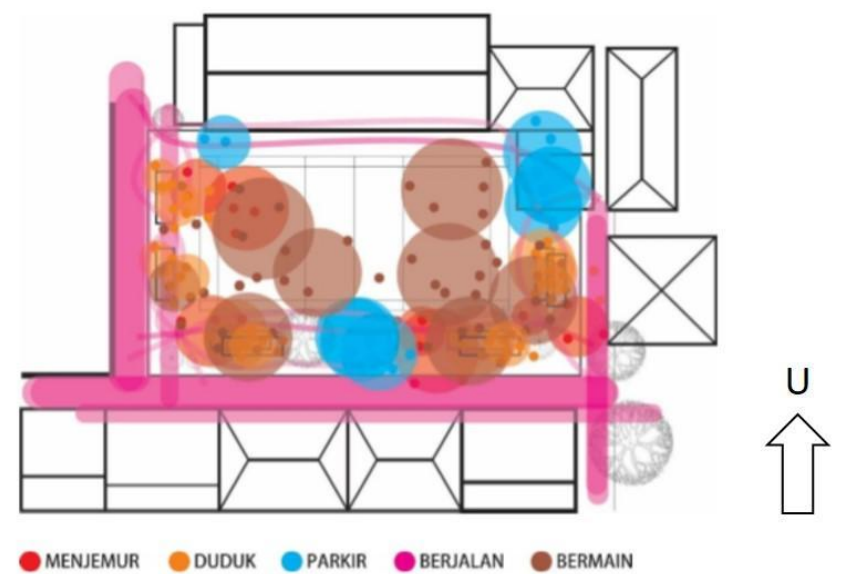

Gambar 10. Mapping Keseluruhan (Hari dan Waktu) Pola Aktivitas Warga di Lapangan Bulu Tangkis Sumber: Analisis Penulis, 2019

Pada Gambar 10, terlihat bahwa hampir seluruh area dari lapangan bulu tangkis (sisi timur, barat, selatan, dan tengah) termanfaatkan oleh pola aktivitas warga sebagai ruang terbuka publik. Namun hal yang sedikit berbeda terlihat pada sisi utara, yakni minimnya pola aktivitas warga yang terjadi di area tersebut. Adapun aktivitas yang terjadi pada sisi utara adalah hanya aktivitas berjalan dengan intensitas yang jarang. Secara lebih detail, pola aktivitas warga secara keseluruhan pada lapangan bulu tangkis di Kampung Gampingan dapat dilihat pada Tabel 5 .

Tabel 5. Rangkuman Pola Aktivitas Warga secara Keseluruhan di Ruang Terbuka Publik Kampung Gampingan 
Kondisi bangunan semi permanen sejajar dan menutup akses serta pemandangan dari rumah yang ada disebaliknya.Atribut ruang terbatas, hanya berupa unsur buatan yakni lampu penerangan dan paving block.

Ruang terbuka di sisi selatan mewadahi berbagai pola aktivitas. Aktivitas yang rutin terjadi sangat beragam dan berlangsung sepanjang waktu berupa duduk, berjalan, bermain, mengobrol, memarkir kendaraan, dan bermain gadget. Ruang terbentuk dari pelingkup bidang horizontal bawah (berupa area terbuka), terhubung langsung dengan jalur sirkulasi kampung dan rumah warga. Atribut ruang berupa kombinasi unsur buatan dan alami berupa: lampu penerangan, tempat duduk, vegetasi, dan perkerasan paving block.

Sisi timur termanfaatkan.

Karakter ruang: passive engagement

Sisi selatan

Sisi barat Keragaman atribut dan hubungan ruang dengan hunian meningkatkan ragam aktivitas. Karakter ruang: active engagement

Aktivitas rutin yang terjadi adalah duduk, berjalan, bermain, mengobrol, memarkir kendaraan dengan perbedaan intensitas pada tiap waktunya. Perbedaan ini disebabkan oleh karena faktor kenyamanan fisik oleh cuaca dan penggunaan ruang untuk kepentingan aktivitas yang bersifat komunal (skala besar). Ruang tersusun dari kombinasi pelingkup bidang horizontal bawah dan atas, serta bidang vertikal. Atribut ruang berupa unsur buatan berupa perkerasan paving block, shelter, dan tempat duduk. Aktivitas rutin yang terjadi pada area ini adalah berjalan, duduk, memarkir kendaraan (pagi-sore-malam), menjemur pakaian (siang). Perbedaan aktivitas disebabkan karena adanya faktor kenyamanan cuaca. Selain itu ada keberadaan area ini juga erat hubungannya dengan fungsi sekitar, yaitu café (fasilitas wifi) dan jalan kampung menuju RT

\section{Keragaman atribut, luasan ruang, dan hubungan ruang dengan hunian meningkatkan ragam aktivitas. Karakter ruang: active engagement}

Keragaman aktivitas terjadi
karena adanya dukungan
fungsi sekitar walaupun
atribut ruang minim. Karakter
ruang: active engagement
yang lain. Ruang tersusun dari dominasi pelingkup elemen horizontal dasar sehingga bersifat terbuka. Atribut ruang berupa tempat duduk dan perkerasan paving block.

Aktivitas rutin yang terjadi adalah menjemur pakaian (pagi-siang), bermain dan berolahraga (sore-malam). Ruang terbentuk dari pelingkup ruang bidang horisontal dasar sehingga cenderung bersifat terbuka, lapang, tanpa sekat/pembatas. Atribut ruang berupa lampu penerangan. Keunggula ruang ini adalah dimensi ruang yang luas. Keragaman aktivitas terjadi
karena adanya keunggulan
dimensi yang dimiliki ruang ini
walaupun atribut ruang minim.
Karakter ruang: active
engagement

Sumber: Analisis Penulis, 2019

Berdasarkan rangkuman pada Tabel 5, dapat ditemukan 2 (dua) karakter kegiatan sebagai ruang terbuka publik yaitu passive engagement dan active engagement. Hal ini disebabkan karena variasi/keragaman atribut ruang pada tiap-tiap area. Keragaman atribut ruang meningkatkan ketertarikan warga untuk menggunakan tiap-tiap area untuk beraktivitas. Perbedaan pola aktivitas juga disebebkan oleh faktor kenyamanan khususnya cuaca, material yang digunakan pada atribut ruang, dan hubungan ruang dengan fungsi di sekitar.

\section{KESIMPULAN}

Secara umum, lapangan bulutangkis di RW 11 RT 51 Kampung Gampingan Yogyakarta merupakan ruang terbuka publik yang sudah dapat menampung berbagai aktivitas masyarakat baik individu maupun kelompok. Terdapat 2 (dua) karakter kegiatan di lapangan bulu tangkis kaitannya sebagai ruang terbuka publik yaitu passive engagement(sisi utara)dan active engagement(sisi selatan, timur, barat, dan tengah).Munculnya 2 (dua) karakter tersebut disebabkan oleh kecenderungan pola aktivitas yang terkonsentrasi pada area tertentu.

Sisi selatan, timur, barat, dan area tengah menjadi area yang cukup dominan dimanfaatkan warga untuk berbagai aktivitas interaksi warga. Berbeda dengan sisi utara yang minim aktivitas interaksi. Hal yang menjadi faktor penentu adanya aktivitas interaksi adalah keragaman atribut 
ruang serta dimensi ruang.Dalam hal ini dapat disimpulkan bahwa keberadaan atribut ruang (baik secara kualitas dan kuantitas)dapat menjadi generator aktivitas. Adanya penambahan atribut ruang dimungkinkan agar pola aktivitas dapat lebih merata dan fungsi lapangan sebagai ruang terbuka publik menjadi lebih optimal.

Dari pengamatan yang dilakukan peneliti, ada beberapa faktor yang mempengaruhi pola aktivitas warga dalam memanfaatkan ruang terbuka publik yaitu: (1) Adanya atribut ruang seperti tempat duduk yang memfasilitasi aktivitas masyarakat;(2)Desain fisik bangunan sekitar yang secara tidak langsung mendukung kelancaran aktivitas di lapangan, seperti fasad rumah yang memiliki tritisan dan menghadap langsung ke ruang terbuka publik;(3)Penggunaan material yang sesuai, seperti perkerasan paving block yang memperlancar beragam aktivitas; (4)Adanya unsur alami berupa vegetasi yang dapat meningkatkan aspek comfort, relaxation, dan discovery (pengalaman meruang) lapangan bulu tangkis sebagai sebuah ruang terbuka publik;(5)Adanya keterhubungan lapangan dengan beragam ruang yang lain yang meningkatkan ketertarikan warga untuk mendatangi dan menggunakan ruang terbuka publik ini;(6)Fasilitas pendukung di sekitar ruang terbuka publik dapat meningkatkan minat warga untuk menggunakan lapangan ini.

Penelitian ini merupakan tahap awal untuk menggali kondisi lokal pada sebuah tatanan ruang terbuka publik di kampung kota. Dari beberapa faktor yang ditemukan, diharapkan dapat digunakan sebagai pertimbangan apabila di kemudian hari akan dilaksanakan kegiatan penataan kawasan kumuh, khususnya dalam hal mempertahankan eksistensi ruang terbuka publik di sebuah kampung, khususnya kampung Gampingan (sebagai kasus penelitian). Peneliti berharap dapat dilakukan penelitian lanjutan terkait preferensi atau hal yang terkait behavioral issue mengingat preferensi dan perilaku seseorang terhadap ruang terbuka publik berbeda sesuai dengan latar belakang pengguna secara sosial budaya, demografi, maupun ekonomi.

\section{DAFTAR REFERENSI}

Barker, Roger. 1968. Ecological psychology: Concepts and Methods for Studying the Environment of Human Behavior. Stanford, CA: Stanford University Press.

Budihardjo, Eko. 2006. Sejumlah Masalah Permukiman Kota. Bandung: PT. Alumni.

Carmona, Matthew, Tim Heath, and Taner Oc Steve Tiesdell. 2010. Public Places, Urban Spaces: The Dimensions of Urban Design. Oxford: Elsevier.

Carr, Stephen. 1992. Public Space. USA: Cambridge University Press.

Fajarwati, Anisah Nur. 2016. "Kajian Behavior Setting di Pasar Tugu Simpang Lima Gumul Kediri." Jurnal Arsitektur NALARs 15 (2): 99-108.

Ghifari, M. Nu'man Al, and Syam Zaki Firdausan. 2019. "Perilaku Masyarakat Pada Ruang Terbuka Publik Di Kampung Kebangsren Surabaya." Sinektika Jurnal Arsitektur 80-86.

Hartati, Ariadne, and Jenny Ernawati. 2018. "Pola Pemanfaatan Ruang pada Taman Tematik di Kota Malang (Studi Kasus : Merbabu Family Park dan Taman Slamet)." Jurnal Mahasiswa Jurusan Arsitektur Universitas Brawijaya 6 (4).

Haryadi, and B. Setiawan. 2010. Arsitektur, Lingkungan, dan Perilaku. Yogyakarta: Gadjah mada University Press. Laurens, Joyce Marcella. 2004. Arsitektur dan Perilaku Manusia. Jakarta: PT Grasindo.

Marhendra, Cantya P., Lisa Dwi Wulandari, and Sigmawan Tri Pamungkas. 2014. "Pola Aktivitas Pemanfaatan Ruang Terbuka Publik Di Alun-Alun Batu." Jurnal Mahasiswa Jurusan Arsitektur Universitas Brawijaya 2 (2): $1-13$.

Nazaruddin. 1994. Penghijauan Kota. Jakarta: Penebar Swadaya.

Pawitro, Udjianto. 2012. "Masyarakat Kampung Kota - Kondisi Permukimannya Dan Upaya Perbaikan Lingkungan Kampung Kota (Studi Kasus RW-12 Kel.Babakan Surabaya Kec.Kiaracondong Kota Bandung)." Seminar Regional Pembangunan Jawa Barat. Bandung.

Popov, Lubomir, and Ivan Chompalov. 2012. "Crossing Over: The Interdisciplinary Meaning of Behavior Setting Theory." International Journal of Humanities and Social Science 2 (19): 18-27.

Pramudito, Sidhi, Antonius Lanang Tegar Wicaksana Praptantya, and David Jeffry Nasir. 2019. "Studi Model Rancangan Hunian Vertikal Berdasarkan Bentuk Interaksi Warga di Bantaran Sungai Winogo Yogyakarta." ARTEKS 3 (2): 149-160. 
Romantiaulia, Weko Indira, and Ainussalbi Al Ikhsan. 2018. "Pola Aktivitas berdasarkan Setting Ruang Terbuka Publik di Kawasan Kampus UHO." Temu Ilmiah Ikatan Peneliti Lingkungan Binaan Indonesia (IPLBI) 7. Semarang: IPLBI. D 077-081.

Setiawan, Bakti. 2010. Kampung Kota dan Kota Kampung: Tantangan Perencanaan Kota di Indonesia (Pidato Pengukuhan Jabatan Guru Besar Dalam Ilmu Perencanaan Kota). Yogyakarta: Universitas Gadjah Mada.

Turner, John F. C. 1972. Freedom to Build: Dweller Control of the Housing Process. New York: Mac Millan Publishing Company. 